\title{
The Effect of Explicit Teaching of Listening Strategies and Gender on EFL Learners' IELTS Performance
}

\author{
Morteza Bagheri \\ Language Department, Payame Noor University, Rasht, Iran \\ Samaneh Karami \\ Language Department, Guilan University, Rasht, Iran
}

\begin{abstract}
The main aim of this study was to investigate the effect of explicit teaching of listening strategies on EFL learners' listening score in IELTS test. The second purpose was to explore the effect of gender on participants' final listening performance. 40 participants at advanced level attended the classes over a period of three months. Participants were divided into control and experimental group. The former that was only exposed to listening input and the latter which received explicit teaching of listening strategies (e.g. selective listening, predicting, and finding key words). Secondly, they were divided into male and female classes. The findings demonstrated that explicit teaching of listening strategies had significant effect on participants' IELTS listening score. However, in terms of the effect of gender, results revealed that gender did not have any effect on participants' IELTS listening score.
\end{abstract}

Index Terms - explicit teaching, EFL learners, gender, IELTS listening score, listening strategies

\section{INTRODUCTION}

For some decades, listening skills have not been taken into account as the first priority by many researchers. Nunan (1997) named listening as Cinderella skill which has been ignored by another skill_ speaking. The influential role of listening in learning English as a foreign language has been considered as one of the least understood of the four language skills. At EFL English classes, good listeners are both scarce and valued. The methods also laid emphasis on productive skills and the relationship between receptive and productive skills were not clear enough (Richards \& Renandya, 2002). However, this trend changed after Krashen's (1982) idea about comprehensible input which caused listening skill to gain its importance again. In addition, in terms of second language acquisition (SLA) listening is an important language skill to develop (Dunkel, 1991; Rost, 2001; Vandergrift, 2007). Also, it has been indicated that a key difference between more successful and less successful acquirers relates in large part to their ability to use listening as a means of acquisition (Rost, 2001).

Researchers have found that learners need to use learning strategies effectively to understand the aural information. This process is vital in learning a second language due to the fact that without these effective strategies, students' listening comprehension will confront some challenges and problems (Mendelsohn, 2006). As a result, over the last three decades, researchers have been laying emphasis on the learning strategies utilized by effective learners and suggested teachers that one of the first priorities in the designing of listening lessons should be to instruct students how to approach listening, how to handle information that is not completely comprehensible (Mendelsohn, 1994, p. 134). Learning strategies are defined as actions adopted by different learners in terms of different learning situations to make learning process somehow faster, more understandable, easier, more effective, and transferrable to new situations and conditions (Oxford, 1990). These strategies are usually developed in order to help students in different academic areas. It is documented that by using instructional techniquesas one of the most effective solutions for students who are dealing with some learning problems, strategy instruction is a good answer and often crucial to students' success (Beckman, 2002; Reid \& Lienemann, 2006).

\section{REVIEW OF RELATED LITERATURE}

In order to improve learners' performance, good listeners use different strategies to meet cognitive challenges. If teachers consider improving listening skills of the learners as the first step specific factors in listening must be identified and taken into account. Therefore, first of all, listeners show several behaviors to inform their communication partners to know that they are ready to focus their attention on the message. After that, they will be quiet, look at the speaker, pay attention to the materials presented by the speaker, and avoid distracting (Owca, Pawlak, \& Pronobis, 2003). Listeners can make comments, ask questions, and respond to questions (Brent \& Anderson, 1993; Owca et al., 2003). There is considerable literature that outlines the most effective method to teach learning strategies (Pressley \& 
Woloshyn, 1995). Rubin (1975) is considered by some researchers as the first scholar in the area of second language acquisition who indicated a direct relationship between learning strategies and good language learners. Most scholars agree that the strategy should be described to the learners, in form of different steps and the advantage of using each strategy should be clarified. It is better to have an accurate description of strategy-based instruction at the beginning.

According to Mendelsohn (1995) cited in Mendelsohn and Rubin (1995), strategy-based instruction in teaching listening skill can be defined as:

"A strategy-based approach is a methodology that is rooted in strategy instruction... It is an approach that sees the objective of the SL/FL course as being to teach students how to listen. This is done first, by making learners aware of how the language functions - i.e., developing metalinguistic awareness, and second, by making them aware of the strategies that they use - i.e., developing what I call "metastrategic awareness." Then, the task of the teacher becomes to instruct learners in the use of additional strategies that will assist them in tackling the listening task.” (p. 134)

Rubin (1975) concluded that good language strategies produce good language learners. Other studies after Rubin argued that good learning strategies were related to effective listening acquisition skills (Chamot, 1995, p. 14). Furthermore, the literature on L2 listening strategies (see for example, Cohen \& Macaro, 2007) shows that there is a significant relationship between strategy use and proficiency. Green and Oxford (1995) summarized a large number of studies that had analyzed the possible relationship between strategy use and proficiency, who concluded that learners at higher proficiency level are more inclined to use more number and illustrated more frequent use of strategies.

Learning necessarily takes place through trial and error, students need therefore plenty of opportunities for such trial (Taylor, 2007). Moreover, as Stahr (2009) asserts that spoken language is identifieded by assimilation as well as unclear articulation, and lexical units are not as important and clear as marked in written text. This means that in absence of clarity, spoken language makes word segmentation an extremely hard task for L2 listeners. Therefore, listening can be regarded as a source of stress for L2 learners (Elkhafaifi, 2005). Noro (2006) examined the psychological aspect of using the term of listening stress instead of listening anxiety by conducting a study by use of questionnaire and oral interviews with Japanese college students. The result showed that the difficulties were some sort of 'stress' to them. According to the literature it is clear that if students can master the skill to control their listening process, they can develop their comprehension as well. Different views towards listening lead to the same classroom pedagogical activities (Richards, 2005).

\section{Theoretical Perspectives on Listening Comprehension}

Nowadays both top-down and bottom-up processing for listening comprehension have shown to be useful; in addition, a combination of both can enhance the results effectivly. Hulstijin(2003) argued that learners' world knowledge and linguistic knowledge inffluence each other and work together to make a mental image of what they have heard. As a result, there is a consunsus that both top-down and bottom-up processes interact with each other make spoken input comprehensible (Vandergrift, 2007). On the other hand, Anderson (2009) provides a compeletly different model from the top-down and bottom-up processes of language comprehension in the field of cognitive psychology. Consequently, he breaks down the language comprehension process into three stages: perception, parsing, and utilization. The first stage involves the perceptual process that encodes the spoken message; the second stage is the parsing stage, in which the words in the message are transformed into a mental representation of the combined meaning of the words. The third stage is the utilization stage, in which listeners use the mental representation of the sentences' meaning. If the sentence is a question, they may answer; if it is an instruction, they may obey.

Also, the studies have focused on the significant difference between more-skilled and less-skilled L2 learners in terms of the top-down and the bottom-up processes have shown considerable evidence of the crucial importance of metacognitive strategies for L2 listeningsuccess (Vandergrift, 2003, 2007; Goh, 2008). Furthermore, Vandergrift's (2003) who studies the adolescent learners of French, faced the fact that skilled listeners reported using about twice as many metacognitive strategies as their less-skilled ones. His study also indicated that two factors could explain together about $39 \%$ of the common variance in L2 listening ability: listening ability and L2 proficiency, with L2 proficiency explaining about 25\% and L1 listening ability about 14\%. Ridgway (2000) argued that activating consciously taught strategies and listening at the same time can be really cumbersome and demanding for learners who have limited cognitive capacity. Still, there are not consunsus over the issue that whether strategy instruction improves learners' listening. Ridgway (2000) pointed out that learners do not have enough cognitive capacity in order to consciously activate taught strategies and listen simultaneously.

Some scholars such as Chang and Read (2006) believed that listening support in tasks can improve learners' performance and use of metacognitive strategies in listening comprehension. Also, they found the effect of listening support on the listening performance of English as a foreign language (EFL) learners. In addition, they understood the fact that various listening tasks can influence the listening strategies that learners use by varying degrees as well as their listening performance. The findings demonstrated the fact that the most effective method of supporting was to provide information about the intended issues as far as possible and then it should be followed by input repetition.

The most methodology used in Englsih classes is known as strategy-based approach. A strategy-based approach is a method of teaching in which strategies mostly used by so-called good listeners are selected for systematic and intensive teaching in the classroom, for instance, predicting, comprehension monitoring, inferencing, clarifying, and summarizing. Furthermore, there are a few number of recent imperical studies which illustrate positive effects of strategy training of 
L2 comprehension on listening (see for example, Graham \& Macaro, 2008; Vandergrift \& Tafaghodtari, 2010). It is worth noting that the experimental effects in both studies indicate a limited instructional value, which in turn hinders to conduct a full scale of listening strategy training in the classrooms as the major syllabus for listening improvement (Hassan et al., 2005; Wang, 2010) and shows the need for following research in the same field. However, it should be noted that the major results of the present studies reveal that metacognitively-based listening strategies can provide a condition in which learners will be more conscious of their learning processes while they are dealing with different kinds of listening. Also, this trend in turn can help learnersfor better and more effective organizing, planning, assessing, and monitoring their learning (see Zeng, 2012).

As it has been mentioned above, the recent studies have investigated different aspects of listening, but no specific research has been conducted exploring the effect of explicit teaching of listening strategies and gender on EFL learners' IELTS listening performance.

\section{METHOD}

\section{A. Participants}

There were forty learners (20 females and 20 males) at advanced level, who have been studying language in different English institutes in Rasht (Guilan, Iran), enrolled in this research. The participants' mother tongue was Persian and nobody has ever been in an English speaking country. All of them were studying at university or graduated. They were between the ages of 21 to 33. Also, based on the pre-test (IELTS test, based on the listening test of IETS test builder book), the participants' listening number was around 5.5 (out of 9, based on IELTS measurement), which revealed the fact that the learners were homogeneous.

\section{B. Listening Strategies}

There have been different strategies that can be taught in an English class such as personalizing, progressive structuring, inferencing, etc. (Nunan, 1997), but for this study selective listening, predicting (guessing), and finding key words (both in questions and listening parts) were taken into account. It was assumed that the aforementioned strategies can have significant effect on the learners' IELTS score. These strategies were connected to content teaching and learners tried to utilize these strategies in different IELTS tests as far as possible to develop their listening skill and improve their score in their final IELTS listening test.

\section{IELTS Listening Classes}

The IELTS classes were an elective course, which were designed for learners who passed the pre-test and showed a level of proficiency to enter these classes. Forty students made up four different classes which each one included ten learners. Each class lasted for one and half an hour and in each session a whole listening part of an IELTS test (40 questions) was covered. Also, participants attended classes twice a week for three months.

\section{Procedure}

Participants were divided into two groups (control and experimental group) that attended in four classes. The first group which included 10 male and 10 female participants composed two classes were received explicit teaching of listening strategies. The second group which contained 20 other participants (10 males, 10 females) made the two other classes were just exposed to listening tests and were asked to answer them during the classes and were informed in terms of their wrong answers and their final scores at the end of each session.

However, my general plan for the experimental group (who received explicit teaching) was to make them practice three different strategies in each session. First, they were asked to underline key words in given tests and then predict what they need (e.g. noun, adjective, number, special name) and guess the related informationtoanswerthe questions. Next, they must have listened and answered the first 10 questions. After that, the listening part was replayed and the participants made clear which part was related to each question and they were helped by the teacher to find key words in listening part which gave signs to answer the questions. By doing this, they practiced selective listening and learned which parts must be skipped. Also, the questions that participants answered incorrectly were more important for further analysis and consideration. Finally, they had to guess about the meaning of some parts of listening which they could not completely understand.However, it was not a blind guess. Learners learned how the words surrounded the intended word can help them to guess more correctly. By doing this; they could improve these three listening strategies. This process was done for the rest three parts of each complete IELTS listening test.

It should be mentioned that in this research predicting and guessing were considered as one strategy because there is considerable overlap between them, therefore, predicting as an umbrella term was utilized in this study to cover guessing too.

\section{E. Research Design}

The study was composed of two independent variables and one dependent variable. The independent variables were teaching listening strategies and gender and the IELTS listening score was independent one. An independent sample ttest was run to calculate the effect of explicit teaching of listening strategies and gender on IELTS score. 


\section{RESUltS}

An independent sample t-test was run on the results of IELTS listening tests to demonstrate the possible differences and similarities between the control and experimental group based on means and $p$ value. In this research the value which was utilized as a critical number to compare the means between the groups known as $\mathrm{p}$ value was 0.05 . The means of IELTS listening score for the control group and experimental group were 28.20 and 35.45, respectively. Therefore, there was a significant difference between two groups in terms of means. Furthermore, the $p$ value of $0.00<0.05$ demonstrated that the two groups were significantly different and there was a meaningful relationship between explicit teaching of listening strategies and IELTS listening score. The results were illustrated in the following tables.

Group Statistics
\begin{tabular}{|ll|l|l|l|l|}
\hline group & N & Mean & Std. Deviation & Std. Error Mean \\
\hline participants' score on IELTS exam control group & 20 & 28.20 & 1.963 & .439 \\
& experimental group & 20 & 35.45 & 1.504 & .336 \\
\hline
\end{tabular}

\begin{tabular}{|c|c|c|c|c|c|c|c|c|c|c|}
\hline & & \multicolumn{2}{|c|}{$\begin{array}{l}\text { Levene's Test } \\
\text { for Equality } \\
\text { of Variances }\end{array}$} & \multicolumn{7}{|c|}{ t-test for Equality of Means } \\
\hline & & \multirow[b]{2}{*}{$\mathrm{F}$} & \multirow[b]{2}{*}{ Sig. } & \multirow[b]{2}{*}{$\mathrm{t}$} & \multirow[b]{2}{*}{ df } & \multirow{2}{*}{$\begin{array}{l}\text { Sig. (2- } \\
\text { tailed) }\end{array}$} & \multirow{2}{*}{$\begin{array}{l}\text { Mean } \\
\text { Difference }\end{array}$} & \multirow{2}{*}{$\begin{array}{l}\text { Std. Error } \\
\text { Difference }\end{array}$} & \multicolumn{2}{|c|}{$\begin{array}{l}95 \% \text { Confidence Interval } \\
\text { of the Difference }\end{array}$} \\
\hline & & & & & & & & & Lower & Upper \\
\hline $\begin{array}{l}\text { participants' score on } \\
\text { IELTS exam }\end{array}$ & $\begin{array}{l}\text { Equal } \\
\text { variances } \\
\text { assumed }\end{array}$ & .648 & .426 & -13.114 & 38 & .000 & -7.250 & .553 & -8.369 & -6.131 \\
\hline & $\begin{array}{l}\text { Equal } \\
\text { variances not } \\
\text { assumed }\end{array}$ & & & -13.114 & 35.586 & .000 & -7.250 & .553 & -8.372 & -6.128 \\
\hline
\end{tabular}

Gender was regarded as the second independent factor in this study which it may have some effects on the participants' IELTS listening score. Based on gender, participants were divided into the male and female group. Then, the independent sample t-test was run to calculate the means of two groups' performance. The means of IELTS listening score were 31.90 and 31.75 for the male and female group. It showed that the two groups werenot significantly different in terms of gender. In addition, the p value of the IELTS listening scores was 0.909 which was higher than $p$ value(0.05) indicating that the two groups were not significantly different. The results are illustrated in the following tables.

Group Statistics
\begin{tabular}{|ll|l|l|l|l|}
\hline group & & $\mathrm{N}$ & Mean & Std. Deviation & Std. Error Mean \\
\hline participants' score on & male & 20 & 31.90 & 4.303 & .962 \\
IELTS exam & female & 20 & 31.75 & 3.905 & .873 \\
\hline
\end{tabular}

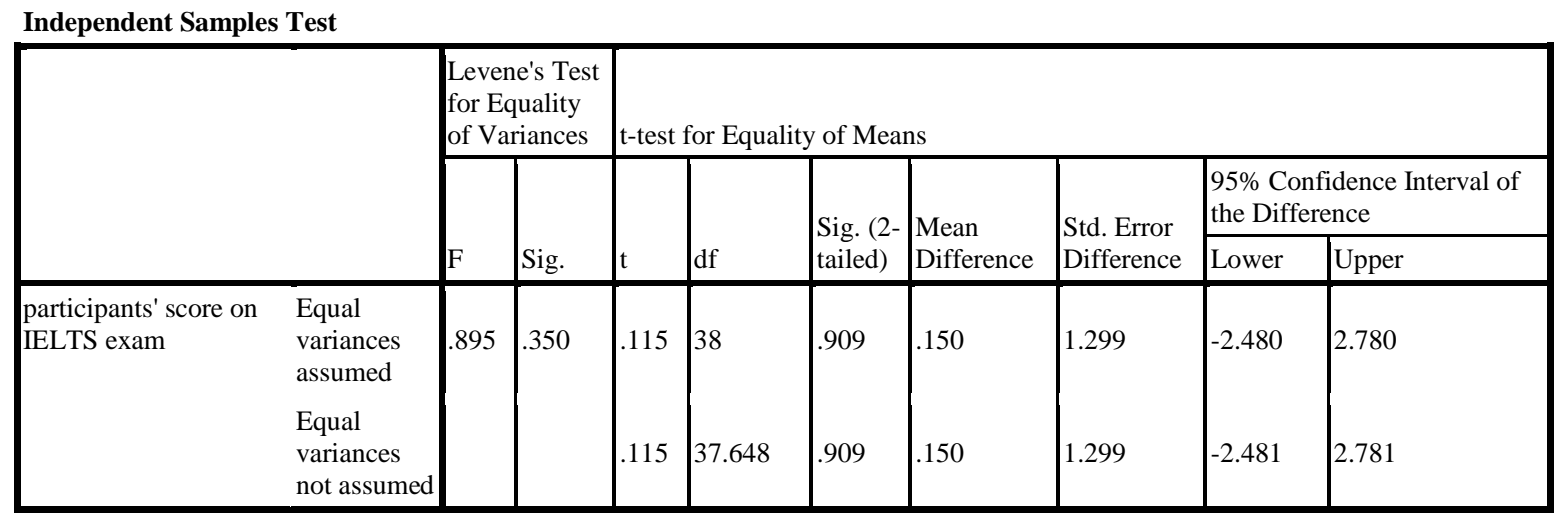

\section{CONCLUSION}

This study was conducted to shed light on the effect of explicit teaching of listening strategies and gender on the participants' IELTS listening performance. Based on these factors (teaching listening strategies and gender) the 
participants were divided into different groups and were exposed to different kinds of teaching which were clarified by the researcher. Therefore, it is very necessary to discuss: first, the effect of explicit teaching of listening strategies on participants' performance and second, the effect of gender on final listening performance.

The findings of this study clarified that explicit teaching of listening strategies could improve participants' IELTS listening score and has positive effect on their final performance. Also, the result of independent sample t-test showed that there was a significant difference between the control and experimental group based on final IELTS listening score $(p<0.05)$. Explicit teaching of listening strategies caused the participants to be familiar with some strategies (selective listening, guessing, and finding key words) which helped them to outperform the participants who were not aware of them. The results of this study are in accordance with the findings of some previous studies that indicated the significant effect of teaching listening strategies on listening performance (e.g. Graham \&Macaro, 2008; Vandergift, \& Tafaghodtari, 2010). On the other hand, the findings of this study are against the idea of comprehensible input (Krashen, 1982) which laid too much emphasis on comprehensible input as the main source of improving learners' knowledge. In addition, the results of this study are in contrast with some studies (e.g. Ridgway, 2000).

In terms of gender, the results of this study demonstrated that gender did not have any effect on the participants' IELTS listening score. In addition, the result of independent sample t-test demonstrated that there was not any significant difference between the male and female participants based on the final IELTS listening scores $(0.909<0.05)$. Therefore, in mixes classes, gender should not be considered as a significant effect on learners learning and syllabus design.

\section{REFERENCES}

[1] Anderson, J. R. (2009). Cognitive psychology and its implications . New York: Worth Publishers.

[2] Beckman, P. (2002). Strategy instruction. ERIC digest, 120-112.

[3] Brent, R. \& Anderson, P. (1993). Developing children's classroom listening strategies. The Reading Teacher, 47, $122-126$.

[4] Chamot, A. U. (1995). Learning strategies and listening comprehension. In D. \&. Rubin, A Guide for the Teaching of Second Language Listening (pp. 13-30). San Diego, California: Dominie Press.

[5] Chang, A. \& Read, J. (2008). Reducing listening test anxiety through various forms of listening support. TESL- EJ, 12-20.

[6] Cohen, A. \& Macaro, E. (2007). Language learner strategies: 30 years of research and practice. Oxford: Oxford University Press.

[7] Dunkel, P. (1991). Listening in the native and second/foreign language: Toward an integration of research and practice. TESOL Quarterly, 25, 431-457.

[8] Elkhafaifi, H. (2005). Listening comprehension and anxiety in Arabic language classroom. The Modern Language Journal, 89 , 206-220.

[9] Goh, C. (2008). Metacognitive instruction for second language listening development: Theory, practice and research implications. RELC Journal, 39, 188-213.

[10] Graham, S. \& Macaro, E. (2008). Strategy instruction in listening for lower-imtermediate learners of French. Language Learning, 58(4), 747-783.

[11] Green, J. \& Oxford, R. L. (1995). A closer look at learner strategies, L2 proficiency and gender. TESOL Quarterly, 29, 261-297.

[12] Hassan, X. M. (2005). Strategy training in language learning- A systematic review of available research. London: University of London.

[13] Hulstijin, J. H. (2003). Connectionist models of language processing and the training of listening skills with the aid of multimedia software. Computer Assisted Language Learning, 16, 413-425.

[14] Krashen, S. (1982). Principles and practice in second language acquisition. Oxford: Pergamon.

[15] McCarte, S. \& Ash, J. (2003). IELTS test builder. London: Macmillan Education.

[16] Mendelsohn, D. (1994). Learing to listen: a strategy based approach for the second language learner. California: Dominie Press.

[17] Mendelsohn, D. (1995). Applying Learing Strategies in the Second/ Foreign Language Listening Comprehension Lesson. In Mendelsohn, D. J.\& J. Rubin, A Guide for the Teaching of Second Language Listening (pp. 55-67). San Diego: Dominie Press.

[18] Mendelsohn, D. (2006). Learning how to listen using learning strategies. In E. \&. Uso-Juan, Current trends in the development and teaching of the four language skills. (pp. 52-65). Boston: Heinle \& Heinle.

[19] Naiman, N. F. (1978). The Good Language Learner. In Stern, Fundemental Concepts of Language Teaching (pp. 82-95). Oxford: Oxford University Press.

[20] Noro, T. (2006). Developing a construct model of "listening Stress": A qualitative study of the affective domain of the listening process. Annual Review of English Language Education in Japan, 17, 61-70.

[21] Nunan, D. (1997). Listening in language learning. The language teacher, 23 (9), 47-51.

[22] Owca, S. Pawlak, E., \& Pronobis, M. (2003). Improving student academic success through the promotion of listening skills. London: Saint Xavier Univesrity.

[23] Oxford, R. (1990). Language learning strategies: What every teacher should know. Boston: Heinle \& Heinle.

[24] Pressley, M. \& Woloshyn, V. (1995). Cognitive strategy instruction that really improves children's academic performance. Cambridge, MA: Brookline Books.

[25] Reid, R. \& Lienemann, T. O. (2006). Strategy instruction for students with learning disabilities: What works for special needs learners? New York, NY: Gilford Publications.

[26] Richards, J. C. (2005). Second thoughts on teaching listening. RELC Journal, 36, 85-92.

[27] Rchards, J. C. \& Renandya, W. A. (2002). Methodology in language teaching: an anthology of current practice. Cambridge : Cambridge University Press.

[28] Ridgway, T. (2000). Listening strategies: I beg your pardon? ELT Journal, 54, 179-185. 
[29] Rost, M. (2001). Teaching and researching listening. London: Longman.

[30] Rubin, J. (1975). A Guide for the Teaching of Second Language Listening. San Diego, California: Dominie Press.

[31] Stahr, L. S. (2009). Vocabulary knowledge and advanced listening comprehension in English as a foreign language. Studies in Second Language Acquisition, 31, 577-607.

[32] Taylor, J. (2007). Introduction: The road to efficiency: The Minimax Teacher. San Diego, California: Viva books private limited.

[33] Thompson, I. \& Rubin, J. (1996). Can Strategy instruction improve listening comprehension? Foreign Language Annals, 29, 331-342.

[34] Vandergrift, L. \& Tafaghodtari, M. H. (2010). Teaching L2 learners how to listen does make a difference: An empirical study. Language Learning, 60(2), 470-497.

[35] Vandergrift, L. (2003). From prediction through reflection: Guiding students through the process of L2 listening. The Canadian Modern Language Review, 59(3), 425-440.

[36] Vandergrift, L. (2007). Recent developments in second and foreign language listening comprehension research. Language Teaching, 40, 191-210.

[37] Wang, L. (2010) Chinese EFL Learners' Listening Comprehension Difficulties-A comparison Between Teacher and Student Perspectives. Unpublished MA thesis, National Institute of Education, Nanyang Technological University, Singapore.

[38] Zeng, Y. (2012). Metacognitive and self-regulated learning (SRL) for Chinese EFL listening development. Unpublished PhD thesis, National Institute of Education, Nanyang Technological University, Singapore.

Morteza Bagheri passed his B.A. and M.A. at Rasht Payam Noor University. He has also been teaching at Islamic Azad University since 2012 and at Shokuh English Institute and IELTS center since 2009. He is interested in teacher training, task-based, and speech act which he has conducted some researches in these areas. He has published on these issues in International Journal of Applied Linguistics and English Literature and International Journal of Social Science and Education.

Samaneh Karami passed her B.A. and M.A. at Guilan University as a top student. She has also taught English at Applied Universities since 2010. Interested in learning strategies, teacher education and psycholinguistics; she has conducted researches under the related topics. She has published on these issues in academic journals like Iranian EFL journal. 